\title{
Stimulation and Development of the Creativity of Engineers through Education Platforms
}

\author{
Nicoleta Daniela IGNAT ${ }^{\star}$
}

\begin{tabular}{l}
\hline \multicolumn{1}{c}{ A R T I C L E I N F O } \\
\hline Article history: \\
Accepted April 2019 \\
Available online April 2019 \\
\hline JEL Classification \\
I20, I25 \\
Keywords: \\
Creativity, Engineers, Education
\end{tabular}

\section{Introduction}

Generally, creativity is the ability to reorganize and combine the data from previous experience to develop something new and original.

According to (Engle, Mah \& Sadri, 1997; Cropley, 1999a), creativity leads to new, relevant and effective ideas.

The ubiquity of change, globalization, the unprecedented development of technologies and science lead to new problems that require new solutions. Thus, all these changes generated by the development of society and technology create new problems that require new solutions. For technological issues, engineers need to provide new creative ideas to provide solutions and solve new challenges.

In the century when the learning device has learned a great deal in many fields from the medical field up to the artistic field, creativity of engineers plays an essential role. Thus, the profitability of organizations is also ensured by the release of new products or services. Many papers address strategies for cultivating and developing creativity (Cropley \& Urban, 2000). Creativity programs have grown more and more and have led to the establishment of a school based on the science of creativity in Canada.

Several programs develop a solid, theoretical basis that demonstrate the effectiveness in terms of creativity. (Badran, 2007; Gangopadhyay, 2014; Zappe, Litzinger and Hunter, 2012; Zappe, Mena, \& Litzinger, 2013).

According to published studies, creativity and education are effective and so the society could benefit from several programs. (Cropley \& Cropley, 2000; Liu \& Schönwetter, 2004; Yeh, 2011).

According to Johri, Chen, \& Lande, creativity is not present as a discipline in engineering programs.

The development of new and effective solutions to problems - in engineering and in general involves passing through synthesis and analysis phases, with specific requirements and requiring unique solutions.

An essential issue in problem solving is represented by the distinct understanding of "solving" as elimination of a difficulty or elimination of an impediment and of "solving" in terms of anticipating, asking or generating questions in order to address more effectively the current situation. The latter is called "problem finding," and it is a proactive process rather than reactive, as well as constructive as it involves introducing a new method of addressing the issue under study.

- Finding mistakes 
- Identification of data

- Identification of problems

- Identifying the idea

- Finding the solution

- Acceptance.

Problem is one of the methods of modern didactics along with brainstorming. This is a method of oral communication being a complex didactic activity, which requires both the students and the professor. The specificity of this method is that the teacher does not communicate, the most important thing is creating situations of a certain degree, choosing the right moment of placement of the problem, manifesting a real interest in solving the topic.

\section{Is stimulated the creativity of technical students through the educational process?}

In Europe, the European and world level recognizes the need to create a creative workforce in the field of engineering for the 21st century. The question is whether engineers are creative and how creativity is stimulated at the level of engineers. Engineers have to generate innovative solutions to the increasingly complex issues of society.

Cropley distinguishes between two types of problem solving:

- routine

- creative

Routine problem solving involves a problem approach using known methods and previously tested / applied, so well-established methods.

Although solving routine problems plays an important role in engineering, solving them often does not lead to innovation.

In order to solve creative problems, which are a constantly changing environment and society, it is necessary to develop new methods, involve new vision and innovation.

Most educational programs focus on routine replication, using algorithms, techniques well known in the art. Students do not benefit from this through study programs followed by enough opportunities to improve their creativity skills to become innovative and creative in the future. This is important because innovative engineering is essential to the development of a competitive economy (Dulgheru et al., 2000]. Cropley argues that there is currently a disconnection between engineering and education largely due to the lack of knowledge of value for creativity in engineering education.

\subsection{Does the MOODLE platform contribute to stimulating creativity?}

The Moodle Platform can contribute to the development of creativity to the extent that on this platform the teachers propose individual and group activities to the students who go through the discipline during that semester.

In order to stimulate student creativity, activities on the Moodle platform must be mandatory for each student / group of students. Thus, the practical work on Moodle should be designed in a way that attracts students to solve them, and these are perceived by them as an attractive game or activity that stimulates them.

If students are not attracted to and involved in solving Moodle applications, teachers should come back with other methods and techniques that will stimulate students' interest, including assigning scores for application solving.

If the Moodle platform is used only for the purpose of posting course support, and other student training materials, it will not really help to stimulate students' creativity.

It is noticed that most of the time in the learning process students learn abstract notions without having their real support. Thus, students appeal especially to memory and very little reason.

Thus, it is necessary to stimulate creativity and engineering creation even to the teaching staff in the university education process

\subsection{Creativity for learning}

In the educational context there is a link between creativity, intelligence and knowledge. Runco in his theories mentions that only intelligence does not guarantee a creative response, but that it is still necessary, however, a threshold of intelligence to achieve a creative output. That threshold of intelligence is determined by the academic performance or linguistic / logical knowledge of a person. (Runco, 2007).

\begin{tabular}{|l|l|}
\hline \multicolumn{1}{|c|}{ Memory Improvement Techniques } & \multicolumn{1}{c|}{ Skills } \\
\hline Ability to recognize relationships between stimuli, & Fluid intelligence \\
understand the implications, and identify the logical & \\
conclusion (can be done using Numerical Inductive \\
Reasoning, Verbal Deductive Reasoning)
\end{tabular}




\begin{tabular}{|l|l|}
\hline \multicolumn{1}{|c|}{ Memory Improvement Techniques } & Skills \\
\hline $\begin{array}{l}\text { The magnitude and depth of acquired general } \\
\text { knowledge, verbal fluency and word comprehension } \\
\text { (Lexical Knowledge, Verbal Fluency, Word Meaning) }\end{array}$ & Crystal intelligence \\
\hline $\begin{array}{l}\text { Ability to retain visual and verbal information in the } \\
\text { short term and to accurately reproduce them (Visual } \\
\text { Short-Term Memory, Verbal Short-Term Memory). }\end{array}$ & Short-term memory \\
\hline $\begin{array}{l}\text { Ability to retain long-term information and update it } \\
\text { with accuracy }\end{array}$ & Long-term memory \\
\hline $\begin{array}{l}\text { Ability to view how objects will look after they have } \\
\text { been rotated or transformed (Visualization). }\end{array}$ & Visual Processing: \\
\hline $\begin{array}{l}\text { Ability to understand and apply mathematical } \\
\text { principles, rules and concepts (Arithmetical }\end{array}$ & Quantitative rationale \\
$\begin{array}{l}\text { Competence, Arithmetical Flexibility, Algebraic } \\
\text { Reasoning). }\end{array}$ & \\
\hline
\end{tabular}

So if intelligence targets factual knowledge, observation, good memory, creativity is based on inventiveness, unusual associations, flexibility. For an engineer to be creative, he / she must develop his / her memory capacity first and then be stimulated by creativity.

\section{Solutions to achieve the creativity of future engineers in the teaching process 3.1 Proposals to stimulate students' creativity}

For the technical field and in the student training process, teachers should focus on ingenuity, value, diversity and utility.

Thus, teachers should primarily provoke interest in the field; and then exemplify concepts using elements (graphical or real), thus creating landmarks for memorization and knowledge.

To foster student creativity, teachers should consider activities to develop:

- the fluidity of thought

- cognitive flexibility

- the originality of the solution / response

- the utility of the solution / response.

Activities that develop the fluidity of thinking can be quantified based on the number of ideas provided by each participant / groups of participants involved in solving a problem. Thus, the fluidity of thinking can be assessed based on the following elements:

- designing the solution

- description of the solution

- materials used

- other issues resolved

The cognitive flexibility that can be quantified based on the types of ideas and for the evaluation can be followed the same elements mentioned above. The originality of the solution can be quantified and evaluated using a scale of $0-10$ in which the answer solution does not bring anything new and 10 is the solution is brilliant. The utility of the solution can also be appreciated on a scale of $0-4$ where 0 does not bring any utility and 4 is indispensable. Thus, both techniques for stimulating individual creativity and group creativity techniques can be addressed.

\subsection{How teachers can contribute to increasing the creative potential of students}

In the process of preparing the students, the teachers can develop the innovative practical work in which the students can be divided into groups of 4 - 5 students during the project / seminar classes in the subjects of the curriculum. The measures that can be transposed in practice by customizing for each discipline in the process of preparation and training of the students are proposed in the table no. $1 .$.

\begin{tabular}{|c|c|c|c|}
\hline $\begin{array}{l}\text { Activities that can be } \\
\text { held in the classroom }\end{array}$ & $\begin{array}{l}\text { Activities that can be } \\
\text { held during seminars }\end{array}$ & $\begin{array}{l}\text { Activities that can be } \\
\text { carried out within the } \\
\text { project hours }\end{array}$ & $\begin{array}{l}\text { Works / Individual } \\
\text { themes }\end{array}$ \\
\hline $\begin{array}{l}\text { Preliminary testing of } \\
\text { students in order to identify } \\
\text { the level of knowledge } \\
\text { gained and the level of } \\
\text { knowledge of the students } \\
\text { in the group / series during } \\
\text { the first lecture. }\end{array}$ & $\begin{array}{l}\text { Focus group activities. } \\
\text { The teacher draws up a set } \\
\text { of questions ( } 6-7 \text { questions) } \\
\text { that make it easier for } \\
\text { students to assimilate new } \\
\text { knowledge. Thus, questions } \\
\text { will be debated in order to }\end{array}$ & $\begin{array}{l}\text { Regularly organizing } \\
\text { sessions of communications } \\
\text { / competitions that are } \\
\text { focused on practical } \\
\text { solutions to various issues } \\
\text { with imposed topics such as } \\
\text { the use of plant design }\end{array}$ & $\begin{array}{l}\text { The theme is based on } \\
\text { technical - scientific } \\
\text { documentation. Thus, } \\
\text { students can propose topics } \\
\text { / topics to be drawn by } \\
\text { them by consulting } \\
\text { scientific publications in the }\end{array}$ \\
\hline
\end{tabular}




\begin{tabular}{|c|c|c|c|}
\hline $\begin{array}{l}\text { Activities that can be } \\
\text { held in the classroom }\end{array}$ & $\begin{array}{l}\text { Activities that can be } \\
\text { held during seminars }\end{array}$ & $\begin{array}{l}\text { Activities that can be } \\
\text { carried out within the } \\
\text { project hours }\end{array}$ & $\begin{array}{c}\text { Works / Individual } \\
\text { themes }\end{array}$ \\
\hline & $\begin{array}{l}\text { provide answers to the } \\
\text { problem / subject } \\
\text { addressed through debates. }\end{array}$ & $\begin{array}{l}\text { programs. } \\
\text { These activities should not } \\
\text { be included as an } \\
\text { assessment activity but } \\
\text { should be part of the } \\
\text { students' practical training. }\end{array}$ & $\begin{array}{l}\text { field. } \\
\text { Documentation should be } \\
\text { done by students by } \\
\text { accessing and consulting } \\
\text { scientific papers / papers } \\
\text { published in specialized } \\
\text { journals over the past 3-5 } \\
\text { years. } \\
\text { Considering that the } \\
\text { scientific works are rapidly } \\
\text { losing their novelty / } \\
\text { actuality they must be } \\
\text { consulted from the last } \\
\text { number to the previous } \\
\text { ones. }\end{array}$ \\
\hline $\begin{array}{l}\text { Systematization of the } \\
\text { knowledge that students } \\
\text { must enroll in the discipline } \\
\text { according to the results } \\
\text { obtained by them at the } \\
\text { previous testing. This will } \\
\text { make it easier for teachers } \\
\text { to facilitate the assimilation } \\
\text { of information. }\end{array}$ & $\begin{array}{l}\text { Applications on small } \\
\text { workgroups } \\
\text { Teachers will prepare } \\
\text { three sets of exercises that } \\
\text { are interdependent and } \\
\text { addressed to the } \\
\text { workgroups. Each working } \\
\text { group analyzes and finds } \\
\text { solutions to solve the } \\
\text { proposed problem. Then } \\
\text { each group of students } \\
\text { presents their results. Thus, } \\
\text { a full session leads to the } \\
\text { detail that can be addressed } \\
\text { in the topic. } \\
\text { Then the teacher points out } \\
\text { what the students have } \\
\text { discovered and points only } \\
\text { those aspects that were not } \\
\text { discovered by the students. }\end{array}$ & $\begin{array}{l}\text { Project ideas to be held on } \\
\text { practical and not theoretical } \\
\text { works }\end{array}$ & $\begin{array}{l}\text { Next week, we'll discuss the } \\
\text { topic "risk management in a } \\
\text { project." } \\
\text { Each working group is } \\
\text { asked to come and present } \\
\text { a risk response strategy. } \\
\text { So each working group } \\
\text { should develop layouts on } \\
\text { the given subject / theme. }\end{array}$ \\
\hline
\end{tabular}

Within the documentation activity, students will be involved in the processing of information. Thus they will appeal to:

- selective perception;

- intelligence;

- creativity;

- critical spirit;

- the motivation of the documentary work.

Subsequently, in order to be transposed within the framework of the topic they are to develop, students will be involved in the selection of the information (this will be done differently by each student considering the fact that the ideas included in a document offer a degree of novelty different for each individual).

To develop the topic, students should also understand the information they have been able to synthesize those elements that, from their point of view, help to solve a problem or have a degree of innovation.

In the work of developing the theme / work, the role of the teacher is to make them aware that each perceives differently the information. Be encouraged to each of them express their opinion according to how they understand.

"Problem solving is another more complex way to apply discovery theories."

\section{Conclusions}

In this context, technical universities have the task and responsibility for "developing inventive and innovative potential for students" from two perspectives:

- Individual - taking into account the wishes, expectations of the students

- Social - given the role of technical universities in the development of technology and society. 
In conclusion, it can be said that regardless of the professional role in which the future technical specialists will work, the role of the creator (research, design, organization) or the role of creative beneficiary (programming-development, management), the educational process forms it, it must take into account the structuring of creative capacities in order to meet the social requirement of progress. There can be no change if in the activities with the students, in the working group there are created conditions that will stimulate creativity. Group activities stimulate the creation of ideas, and often the ideas of some people are generated or enriched by the ideas of others.

\section{References}

1. Cropley, A. J., \& Urban, K. K., 2000. Programs and strategies for nurturing creativity. In K. A. Heller, F. J. Mönks, R. J. Sternberg, \& R. F. Subotnik (Eds.). International handbook of giftedness and talent, pp. 481-494. Oxford: Permagon

2. Badran, I., 2007. Enhancing creativity and innovation in engineering education. European J. of Engin. Education, 35(2), pp. 573-585.

3. Gangopadhyay, D., 2014. The dawn of the creative age: Fostering creativity among engineering students. Teaching Innovation Projects, 4(1) Art. 4.

4. Glover, J. A. (1980). A creativity-training workshop: Short-term, long-term, and transfer effects. Journal of Genetic Psychology, 136(1), pp. 3-16.

5. Zappe, S., Litzinger, T., \& Hunter, S. (2012). Integrating the creative process into engineering courses: Description and assessment of a faculty workshop. Paper Presented at the Annual Conference of the American Society for Engineering Education, pp. 1-15.

6. Zappe, S., Mena, I., \& Litzinger, T. (2013). Creativity is not a purple dragon. Paper Presented at the OPEN 2013, NCIIA'S 17th Annual Conference, pp. 1-13.

7. Cropley, D. H., \& Cropley, A. J., 2000. Fostering creativity in engineering undergraduates. High Ability Studies, 11(2), pp.207-219.

8. Liu, Z. E., \& Schönwetter, D. J., 2004. Teaching creativity in engineering. International Journal of Engineering Education, 20(5), pp. 801-808.

9. Yeh, Y.-C., 2011. Research and methods. In M. Runco, \& S. Pritzker (Vol. Eds.), Encyclopedia of creativity: Vol. 2, pp. 291298. USA: Academic Press.

10. Johri, A., Chen, H. L., \& Lande, M., 2009. Creativity and cognition in engineering design: Theoretical and pedagogical issues. Paper Presented at the Seventh ACM Conference on Creativity and Cognition Berkeley, pp. 487-488

11. Kazem Kazerounian and Stephany Foley, 2007. "Barriers to creativity in engineering education: A Study of instructors and students perceptions," Journal of Mechanical Design, vol. 129, no. 7, pp. 761-768.

12. Dulgheru, V., Cantemir, L., Carcea, M. (2000), "Manual de creativitate", Editura Tehnica Info Chisinau,

13. Runco, M. A. (2007), “Creativity: theories and themes: research, development, and practice”, Amsterdam; London: Elsevier Academic Press. 